\title{
Relationship between a Reduced Aroma Production and Lipid Metabolism of Apples after Long-term Controlled-atmosphere Storage
}

\author{
A. Brackmann', J. Streif ${ }^{1}$, and F. Bangerth \\ Institut für Obstbau, Universität Hohenheim, 7000 Stuttgart-70, Germany
}

Additional index words. Malus domestica, ripening, volatiles

\begin{abstract}
Golden Delicious' apples (Malus domestica Borkh.) harvested at the preclimacteric and climacteric stages of ripening were stored for up to 8 months at $1 \mathrm{C}$ in air and under various controlled atmosphere(s) (CA), including ultralow oxygen (ULO) storage conditions. Aroma volatiles were measured at 2-month intervals in fruit ripened for 10 days at $20 \mathrm{C}$. Fruits harvested at the climacteric stage produced more volatiles during all storage conditions than preclimacteric fruit. All CA storage treatments suppressed aroma production compared to cold storage. The greatest reduction was found under ULO $\left(1 \% \mathrm{O}_{2}\right)$ and high $\mathrm{CO}_{2}(3 \%)$ conditions. A partial recovery of aroma production was observed when CA fruits were subsequently stored for 14 days under cold storage conditions. Suppression of aroma production under ULO conditions seems to be related to low fatty acid synthesis and/or degradation, and is restricted to volatiles having a straight $\mathrm{C}$ chain. Production of branched $\mathrm{C}$-chain aroma compounds was suppressed by high $\mathrm{CO}_{2}$ concentrations. The reduced capacity of aroma production during shelf life after ULO storage is confined to apple cultivars producing mainly ester compounds with a straight C-chain, e.g., 'Golden Delicious'.
\end{abstract}

CA storage, in particular ULO, diminishes the loss of firmness, acidity, chlorophyll, and sugar of the fruit and reduces the incidence of some physiological disorders in comparison with cold storage of apples (Bohling and Hansen, 1985; Schouten, 1988; Streif, 1985). However, CA conditions suppress flavor development in apples (Shatat et al., 1978; Streif and Bangerth, 1988). The suppression depends on both the composition of the storage atmosphere and the length of storage. In general, suppression of volatile production is particularly marked under conditions that delay ripening (Hatfield and Patterson, 1975). The phenomenon of decreasing aroma production has been observed in 'Cox Orange' (Knee and Hatfield, 1981), 'Golden Delicious' (Streif and Bangerth, 1988), and 'McIntosh' (Lidster et al., 1981).

Reasons for the suppression of aroma production after CA storage are not fully understood. Patterson et al. (1974) attribute the decline in aroma volatiles of long-term-stored apples to a loss of substrates or enzymes essential for the formation of esters. Hatfield and Patterson (1975) suggest a connection between inhibition of respiration after CA storage and suppression of aroma production. According to Knee and Hatfield (1981), the production of esters by 'Cox Orange' in low $\mathrm{O}_{2}$ atmosphere is limited by the availability of alcohols from which the aroma esters are derived. Bangerth and Streif (1987) suggest that changes in the sensitivity of fruits to $\mathrm{C}_{2} \mathrm{H}_{4}$ might be responsible for the decline in aroma production by 'Golden Delicious' because inhibition of $\mathrm{C}_{2} \mathrm{H}_{4}$ biosynthesis and/or action under cold storage conditions gave similar effects on volatile production (Bangerth and Streif, 1987; Halder-Doll and Bangerth, 1987). High $\mathrm{CO}_{2}$ concentrations in combination with ULO conditions further suppress aroma production in shelf life. DePooter et al. (1987) indicated that the antagonistic effect of high $\mathrm{CO}_{2}$ concentrations on aroma production might not only interfere with alcohol dehydrogenase (EC

Received for publication 16 Sept. 1991. Accepted for publication 3 Sept. 1992. This research was supported in part by a grant from the German Academic Exchange Service (Deutscher Akademischer Austauschdienst). The cost of publishing this paper was defrayed in part by the payment of page charges. Under postal regulations, this paper therefore must be hereby marked advertisement solely to indicate this fact.

${ }^{1}$ Versuchsstation für Obstbau, 7980 Ravensburg-Bavendorf, Germany.
1.1.1.1), which catalyses the synthesis of alcohols from aldehydes, but also with carboxylic acid metabolism.

The pathway of ester synthesis in apples is not completely understood. Studies of lipid metabolism in apples indicated an enhanced turnover of lipids during ripening (Bartley, 1985), and the long chain liberated fatty acids are thought to be precursors for some of the esters (Bartley, 1986). Also, amino acids serve as precursors for the synthesis of aroma volatiles in apples (Tress1 et al., 1970).

The purpose of this investigation was to determine the effect of various storage conditions, especially ULO, on the production of aromatic volatiles and fatty acids during ripening. Further, this investigation evaluated the effect of several poststorage treatments on aroma production after long-term ULO storage.

\section{Materials and Methods}

Apples from 'Golden Delicious' trees grown on M 9 rootstocks were used for the experiments. The fruits were harvested either at the preclimateric or climateric ripening stages, as determined by internal ethylene concentrations $\left(<0.05 \mu \mathrm{l} \cdot\right.$ liter $^{-1}$ and $>0.6 \mu \mathrm{l} \cdot$ liter $^{-1}$, respectively) and $\mathrm{CO}_{2}$-production. Immediately after picking, fruits were selected for uniformity and stored at 1C. For CA storage, 40 $\mathrm{kg}$ of apples were placed in 240-liter containers. The concentrations of $\mathrm{CO}_{2}$ and $\mathrm{O}_{2}$ were continuously monitored by gas analysers connected to a process computer. To achieve $\mathrm{CO}$, absorption in the low $\mathrm{CO}$, atmospheres $(<1 \% \mathrm{CO} 2)$ it was necessary to place $\mathrm{Ca}(\mathrm{OH})_{2}$ in the container. Excess $\mathrm{CO}$, in the other CA containers was removed by $\mathrm{N}_{2}$ flushing. Storage conditions were: air storage: $3 \%$ $\mathrm{CO}_{2}+3 \% \mathrm{O}_{2} ; 3 \% \mathrm{CO}_{2}+1 \% \mathrm{O}_{2} ;<1 \% \mathrm{CO}_{2}+1 \% \mathrm{O}_{2}$. During 8 months of storage, $1-\mathrm{kg}$ samples of fruit in each of two replicates were removed from the storage containers at 2-month intervals and placed in separate gas-tight glass jars at 20C for 10 days. These were continuously ventilated with air at a rate of $11.3 \mathrm{liter} \cdot \mathrm{h}^{-1}$. After 3,6 , and 9 days of ripening, 2 liters of air from the jars was passed through Pasteur pipettes in which activated charcoal adsorbed the

Abbreviations: CA, controlled atmosphere; ULO ultralow oxygen. 
volatiles. The pipettes were directly inserted into the injection port of a gas chromatograph and the desorbed volatiles analysed on a packed Carbowax 20M column (Streif, 1981). Retention indices of authentic standards (Roth, FRG) were used to identify the 15 most important volatiles. Restriction to these 15 compounds was possible because earlier methodological experiments had shown that most of the volatile substances produced in smaller amounts were similar in production trends as the major compounds.

The wax and fatty acid composition of the fruit peel was determined after 7 months of storage in one of the two above replicates. For these determinations, 200 disks $1.2 \mathrm{~cm}$ in diameter from five fruits were taken for each storage treatment. Wax and fatty acids were extracted with petroleum ether in a Soxhlet apparatus for $3 \mathrm{~h}$. Gas chromatography of the lipids and fatty acids was done according to Neubeller (1971).

In an additional poststorage treatment, six samples (seven fruits each) from the $3 \% \mathrm{CO}_{2}+1 \% \mathrm{O}_{2}$ atmosphere were removed after 8 months of storage and stored in air at $1 \mathrm{C}$ for 2 weeks. The fruit was then ripened as stated above.

To evaluate the effect of exogenous aroma precursors, fruit (three randomized samples of five apples each) from the $3 \% \mathrm{CO}$, $+1 \% 0$, atmosphere were taken after 7 months of storage, enclosed in 5-liter jars, and held at 20C. The various alcohols, aldehydes, organic acids, and esters (Table 1) were directly injected onto a filter paper in the jars, the total final concentration in the jar being $160 \mu \mathrm{l} \cdot$ liter $^{-1}$. After $24 \mathrm{~h}$, the samples of apples were transferred to ventilated jars for 10 days of ripening and then volatiles analysed as described by Streif (1981). Production was determined after 1, 5 , and 9 days of ripening.

\section{Results}

The main constituents in the aroma volatiles of 'Golden Delicious' were esters of which butyl and hexyl acetate represented $\approx 60 \%$ of the total volatile production of ripe fruits (Fig. 1). Fruits harvested at the climacteric stage produced more volatiles than preclimacteric fruits under all storage conditions and removal dates (Fig. 2). CA storage conditions suppressed the aroma production in comparison to air storage. In general, the production of volatiles was negatively affected by low $0,(1 \%)$ and high $\mathrm{CO}$, (3\%) concentrations. The greatest suppression of volatiles was caused by ULO $\left(3 \% \mathrm{CO}_{2}+1 \% \mathrm{O}_{2}\right)$, and suppression was accentuated with increasing storage time. ULO especially suppressed compounds with a straight C-chain, such as butyl acetate (Fig. 3).

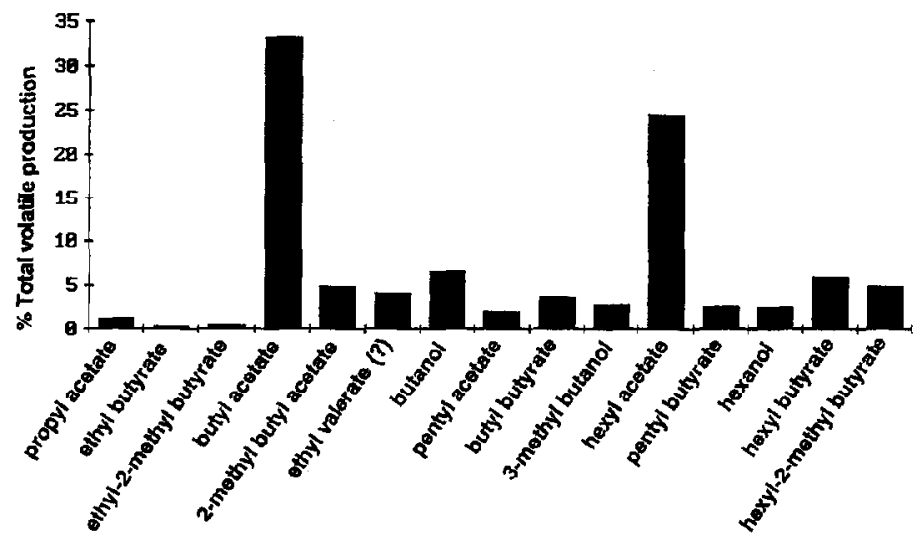

Fig. 1. Relative amount of the 15 most important aroma volatiles of 'Golden Delicious' apples (see Material and Methods) at harvest and ripened for 9 days at $20 \mathrm{C}$. Peak identity was done by comparison of retention times with reference standards.
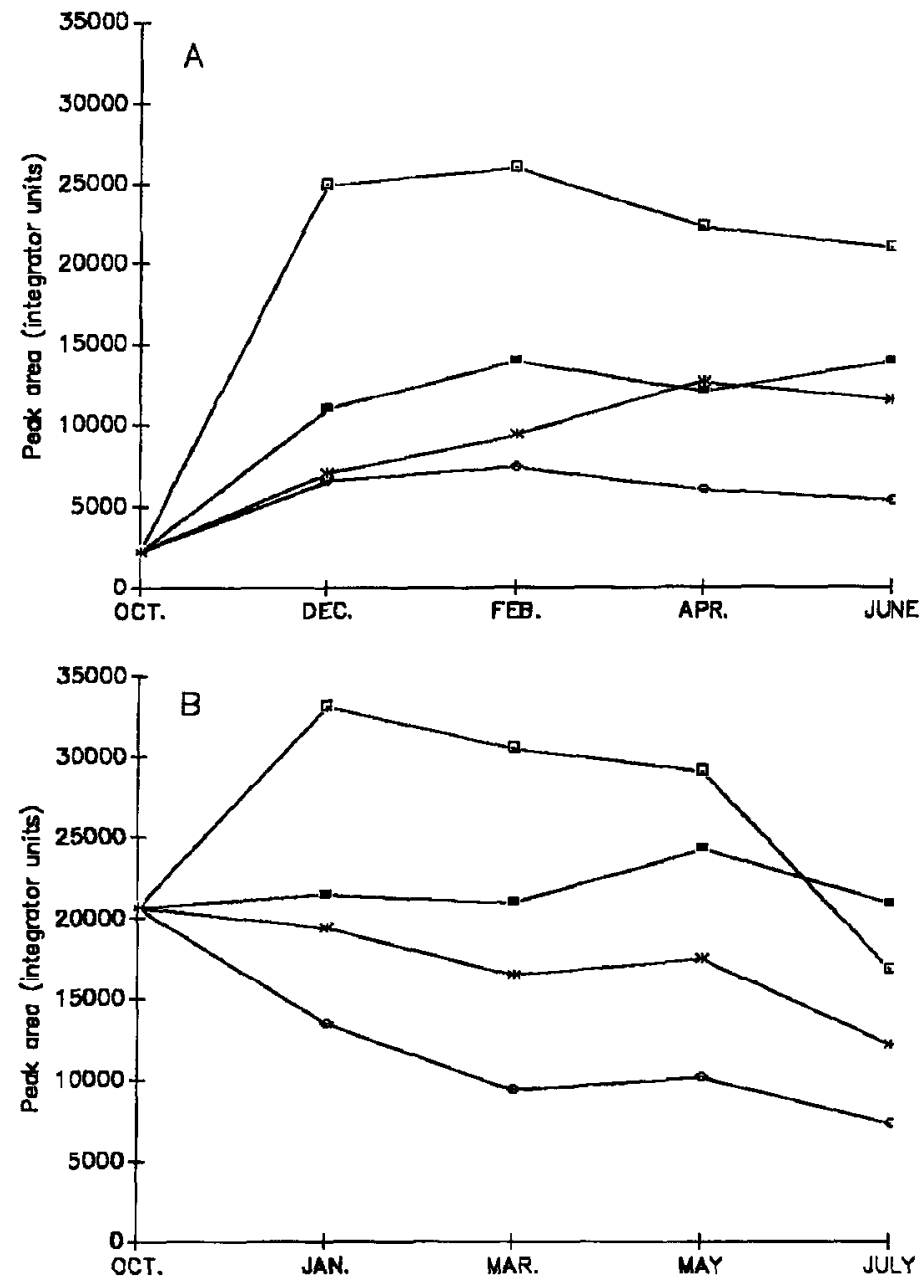

Fig. 2. Total volatile production of (A) preclimacteric and (B) climacteric 'Golden Delicious' apples during 8 months of storage at $1 \mathrm{C} . \square$ air storage; $\square \mathrm{CA} 3 \% \mathrm{CO}_{2}$ $+3 \% \mathrm{O}_{2} ; \boldsymbol{\Theta} \mathrm{CA} 3 \% \mathrm{CO}_{2}+1 \% \mathrm{O}_{2}(\mathrm{ULO}) ; \mathrm{CA}<1 \% \mathrm{CO}_{2}+1 \% \mathrm{O}_{2}$.

Production of compounds with a branched C-chain, such as 2methyl butyl acetate and 2-methyl butanol, was not suppressed by low $\mathrm{O}_{2}$ but by high $\mathrm{CO}_{2}$ after long-term storage (Figs. 4 and 5).

The amount of fatty acids in the peel increased with storage time, e.g., in air-stored fruits, from 18 to $45 \mu \mathrm{g} \cdot \mathrm{cm}^{-2}$ over 7 months. Production, however, was inhibited by low $\mathrm{O}_{2}$ and high $\mathrm{CO}_{2}$, a possible reason for the lowest concentration being found in ULO (Fig. 6). Synthesis of linoleic acid was suppressed the most. In contrast, the wax content of the skin was not influenced by storage conditions. After 8 months in store, the wax content of all treatments was $\approx 400 \mu \mathrm{g} \cdot \mathrm{cm}^{-2}$.

Air storage at $1 \mathrm{C}$ for 2 weeks immediately after 8 months of ULO storage greatly improved production of volatiles during ripening. This treatment, however, failed to allow a complete recovery of the potential for aroma production in comparison with air storage (Fig. 7).

In the experiment in which aroma precursors were added to long-term ULO-stored fruits, the apples showed an intensive turnover of these substances as indicated by changes in the concentration of compounds produced from them (Table 1). One mechanism by which the precursors could be transformed is B-oxidation forming compounds having two fewer $\mathrm{C}$ atoms. Exogenous butyrate, e.g., was reduced to butanol, but mainly degraded by $B$ oxidation to ethanol, which was then partly esterified to ethyl 


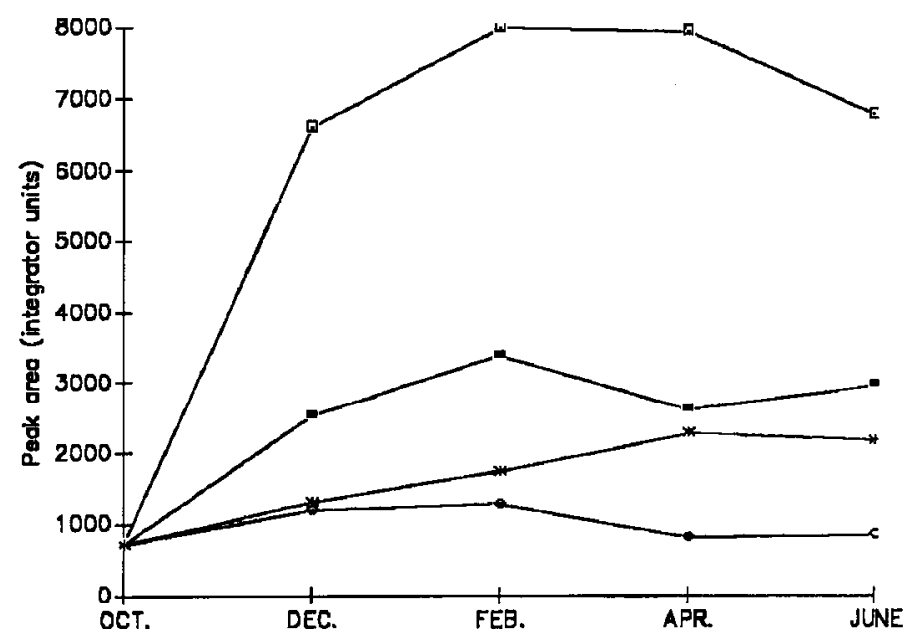

Fig. 3. Production of butyl acetate of preclimacteric 'Golden Delicious' apples during 8 months of storage at $1 \mathrm{C}$. $\square$ air storage; CA $3 \% \mathrm{CO}_{2}+3 \% \mathrm{O}_{2} ; \ominus \mathrm{CA}$ $3 \% \mathrm{CO}_{2}+1 \% \mathrm{O}_{2}(\mathrm{ULO}) ; \mathrm{CA}<1 \% \mathrm{CO}_{2}+1 \% \mathrm{O}_{2}$.

butyrate. The aldehyde butanal was oxidized or partly reduced to its corresponding acid and alcohol, which were subsequently combined in ester compounds such as ethyl isobutyrate, butyl- or pentyl butyrate. The supplied ester, methyl acetate, was hydrolized, and the formed acid was reduced to alcohol and then esterified with another acid preferentially forming ethyl isobutyrate. The three most prominent volatile compounds, viz. butyl acetate, 2-methyl butylacetate, and hexyl acetate, were surprisingly little or not at all affected by the precursors applied. Since unlabeled precursor compounds were used for these experiments, our conclusions have to be viewed as tentative.

\section{Discussion}

It is generally accepted that apple volatiles are synthesized enzymatically by coupling the respective acid and alcohol moieties (Salunkhe and Do, 1976). The straight-chain fatty acids can be formed by P-oxidation of long chain fatty acids (Bartley, 1986) and the branched-chain acid moieties from amino acids (Tress1 et al., 1970).

Butyl and hexyl acetate, the most abundant volatiles produced

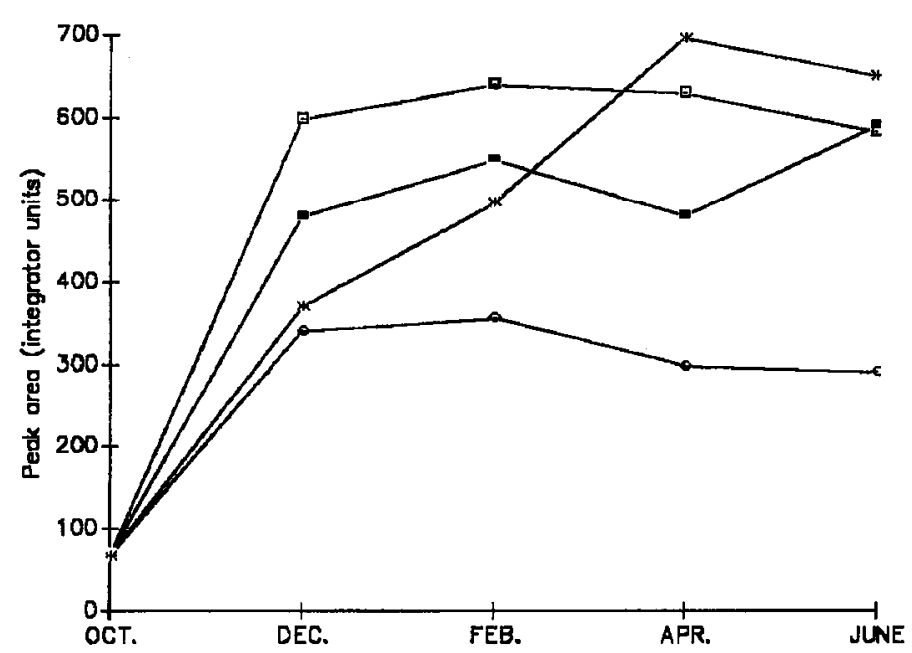

Fig. 4. Production of 2-methyl butanol of preclimacteric 'Golden Delicious' apples during 8 months of storage at $1 \mathrm{C} . \square$ air storage; $\mathrm{CA} 3 \% \mathrm{CO}_{2}+3 \% \mathrm{O}_{2}$; $\mathrm{\Theta CA}$ $3 \% \mathrm{CO}_{2}+1 \% \mathrm{O}_{2}(\mathrm{ULO}) ; \mathrm{CA}<1 \% \mathrm{CO}_{2}+1 \% \mathrm{O}_{2}$.

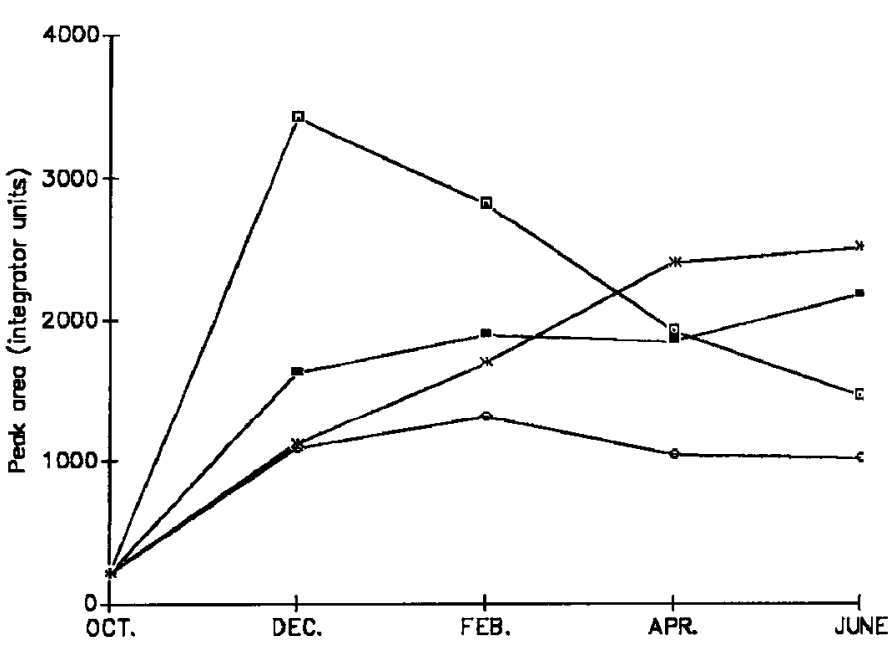

Fig. 5. Production of 2-methyl butyl acetate of preclimacteric 'Golden Delicious' apples during 8 months of storage at $1 \mathrm{C} . \square$ air storage; $\mathrm{CA} 3 \% \mathrm{CO}_{2}+3 \% 0$; $\odot \mathrm{CA} 3 \% \mathrm{CO}_{2}+1 \% \mathrm{O}_{2}(\mathrm{ULO}) ; \mathrm{CA}<1 \% \mathrm{CO}_{2}+1 \% \mathrm{O}_{2}$.

by 'Golden Delicious' (Fig. 1), are formed from butanol and hexanol combining with acetate derived from the metabolism of fatty acids (Bartley, 1986). Among the 15 aroma volatile compounds evaluated in this study it was evident that production of esters and alcohols with straight chains was strongly suppressed by long storage times under ULO. However, esters with branched-chains were not suppressed under these conditions. Only under high $\mathrm{CO}_{2}$ (3\%) concentrations did the production of these substances decline.

The suppression of volatiles with straight $\mathrm{C}$-chains under ULO could be related to the influence of low $\mathrm{O}_{2}$ concentrations on lipid metabolism and/or synthesis. Measurements of the fatty acid content and composition in the fruit peel, which probably reflect fatty acid composition in the cortex, confirms that low 0 , and high $\mathrm{CO}_{2}$ concentrations reduce the levels of all fatty acids, especially linoleic acid. This finding agrees with that of Schmitz (1968), who

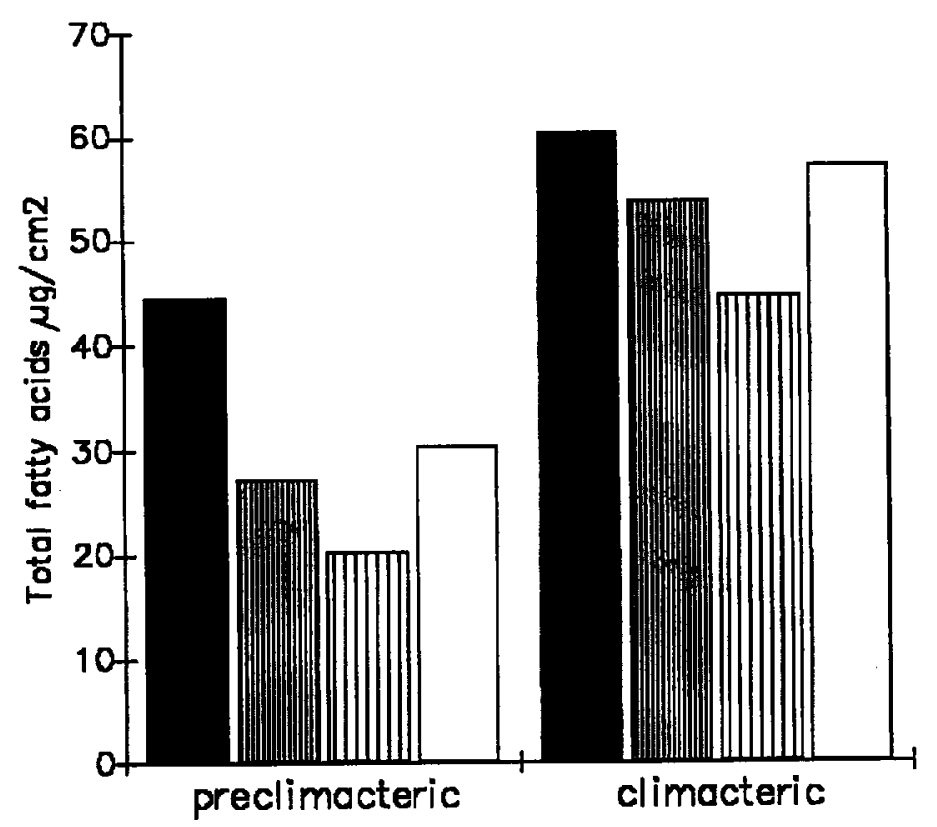

Fig. 6. Total fatty acid content in the peel of 'Golden Delicious' apple fruits after 7 months of storage. Fatty acids determined were: palmitic, stearic, oleic, linoleic,

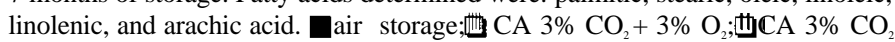
$+1 \% \mathrm{O}_{2}(\mathrm{ULO}) ; \square \mathrm{CA}<1 \% \mathrm{CO}_{2}+1 \% \mathrm{O}_{2}$. 


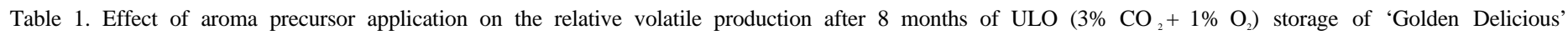
apple fruits at $1 \mathrm{C}$.

\begin{tabular}{lcccccccccccccc}
\hline & \multicolumn{10}{c}{} & \multicolumn{10}{c}{ Volatiles produced $^{z}$} \\
\cline { 2 - 14 } Precursor & EA & E & EI & PrA & EB & P & BA & MBA & B + PA & BB & HA & PB & H & HB \\
\hline Ethanol & $47^{y}$ & 652 & 0.8 & 0.2 & 241 & 5.1 & 2.0 & 1.1 & 2.3 & 0.5 & 1.4 & 1.3 & 0.6 & 0.9 \\
Propanol & 0.2 & 0.8 & 0.8 & 41 & 0.9 & 1529 & 0.1 & 1.3 & 1.5 & 0.2 & 0.7 & 24 & 1.0 & 0.4 \\
Butanol & 4.8 & 0.2 & 71 & 1.5 & 0.9 & 1.8 & 1.9 & 0.1 & 79 & 16 & 0.6 & 8.3 & 2.2 & 1.7 \\
Pentanol & 0.5 & 27 & 0.9 & 3.2 & 1.0 & 56 & 0.1 & 0.2 & 26 & 0.1 & 0.1 & 0.8 & 0.7 & 6.2 \\
Hexanol & 1.7 & 602 & 0.7 & 0.1 & 1.0 & 1.5 & 0.3 & 0.3 & 5.2 & 1.1 & 14 & 14 & 129 & 1.2 \\
Octanol & 2.4 & 257 & 0.7 & 0.1 & 1.0 & 0.2 & 0.7 & 0.3 & 4.2 & 0.8 & 1.1 & 15 & 5.2 & 0.4 \\
Butyric acid & 3.5 & 113 & 0.8 & 0.1 & 80 & 0.1 & 0.8 & 0.3 & 4.8 & 6.5 & 0.5 & 0.8 & 1.5 & 2.0 \\
Butyraldehyde & 2.4 & 12 & 2406 & 0.2 & 1.2 & 0.4 & 1.9 & 0.1 & 54 & 18 & 0.3 & 24 & 1.6 & 2.5 \\
Methyl acetate & 0.6 & 0.6 & 2.3 & 1.0 & 0.6 & 1.0 & 1.1 & 1.8 & 1.7 & 1.2 & 1.2 & 1.2 & 0.7 & 1.8 \\
Control & 320 & 30 & 1 & 261 & 1 & 25 & 2728 & 992 & 647 & 501 & 3578 & 50 & 916 & 917 \\
\hline
\end{tabular}

${ }^{2} \mathrm{EA}=$ ethyl acetate, $\mathrm{E}=$ ethanol, EI = ethyl isobutyrate, PrA = propyl acetate, $\mathrm{EB}=$ ethyl butyrate, $\mathrm{P}=$ propanol, $\mathrm{BA}=$ butyl acetate, MBA = 2-methyl butyl acetate, $\mathrm{B}+\mathrm{PA}=$ butanol + pentyl acetate, $\mathrm{BB}=$ butyl butyrate, $\mathrm{HA}=$ hexyl acetate, $\mathrm{PB}=$ pentyl butyrate, $\mathrm{H}=$ hexanol, $\mathrm{HB}=$ hexyl butyrate. ${ }^{y}$ Factors by which the volatile production (integrator units) of control fruits get multiplied after the application of the various precursors.

${ }^{x}$ Volatile production (integrator units) from fruit with no added precursors.

observed inhibition of unsaturated fatty acid synthesis during CA storage of 'Golden Delicious' apples. The unsaturated fatty acids, such as linoleic acid, need $\mathrm{O}_{2}$ for their synthesis (Stumpf, 1980). This fact could partly explain the inhibition of unsaturated fatty acid synthesis under low $\mathrm{O}_{2}$ concentration. However, low $\mathrm{O}_{2}$ and high $\mathrm{CO}_{2}$ concentrations could inhibit respiration and general metabolism, thus reducing the supply of energy equivalents, such as NADPH, that are needed for the synthesis of fatty acids during the ripening of the fruit (Drawert, 1975). This explanation is relevant because inhibition of ethylene biosynthesis and/or action also inhibits respiration and the production of unsaturated fatty acids and aroma volatiles, irrespective of 0 , concentration in the storage atmosphere (Halder-Doll and Bangerth, 1987).

The experiment with aroma precursors shows that fruits are capable of synthesizing alcohols and esters from exogenously supplied precursors after 8 months of ULO storage. This means that enzymes in the last steps of ß-oxidation, viz. alcohol dehydrogenase and esterase, are active. This leads to the conclusion that

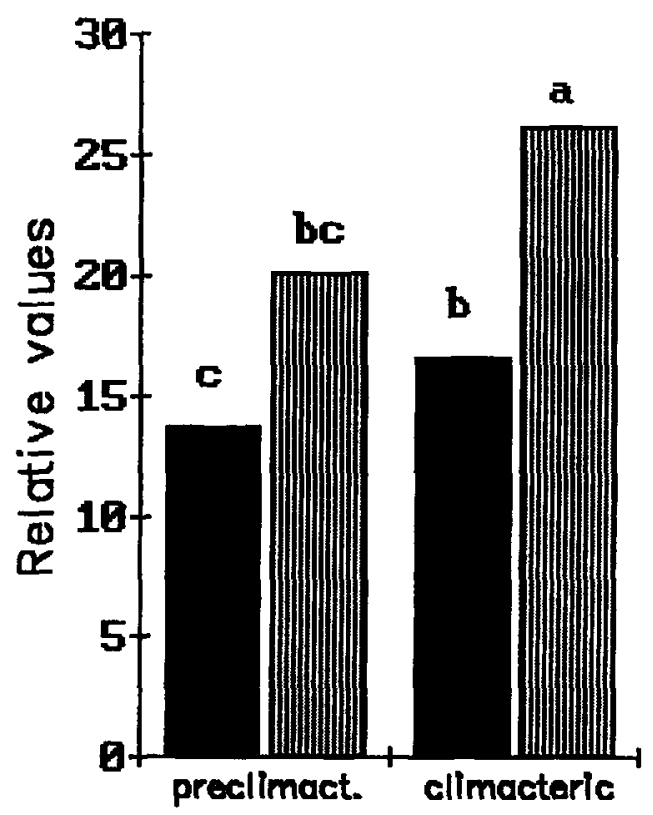

Fig. 7. Effect of air storage at $1 \mathrm{C}$ following 8 months of ULO storage on aroma production of 'Golden Delicious' apple fruits. ICA storage; 曲CA storage +14 days in air at 1C. Means with different letters are significantly different at $P=0.05$. low 0 , limits the availability of alcohols from which esters are derived (Knee and Hatfield 198 1). Inhibition of fatty acid biosynthesis and/or degradation could be another reason for the lack of alcohol precursors, thus low volatile production after ULO storage. If impairment of fatty acid degradation is the reason, then the limiting step would be expected to be early in the catabolism of these compounds, since precursors of the size of octanol and smaller are easily metabolized by ULO fruits (see Table 1). Oxidation of, e.g., linoleic acid by lipoxygenase (EC 1.13.11.12), which requires $\mathrm{O}_{2}$ and yields hexanal besides three larger molecules (aldehydes, acids) (Drawert, 1975), is a more likely alternative for these first steps than B-oxidation.

Since high $\mathrm{CO}_{2}$ concentrations suppress the production of aroma compounds with branched and unbranched C-chains, then high $\mathrm{CO}_{2}$ probably affects the metabolism of amino acids and fatty acids. Rolle (1968) concluded that apple cultivars synthesizing comparatively large amounts of "branched volatiles" produce the alcohol precursors for these substances mainly from amino acids. The tricarboxylic acid cycle, from which most amino acid precursors are derived, is inhibited by elevated $\mathrm{CO}_{2}$ (Frenkel and Patterson, 1973). Thus, the influence of $\mathrm{CO}_{2}$ on the production of volatiles is one of suppressed amino acid metabolism.

Drawert et al. (1972) classified apple cultivars by their volatile composition into two types: the "ester-type" and the "alcoholtype." Whereas the alcohol-type cultivars produce most of their volatile precursors from amino acids, the precursors of the estertype cultivars originate mainly from fatty acids. Taking this information into account, we hypothesize that the suppression of aroma volatiles during shelf life, after ULO storage, is important only for the ester-type apple cultivars, such as 'Cox Orange', 'Golden Delicious', 'Jonathan', etc. Therefore, attempts to improve the volatile aroma production of "ester-type" apple cultivars stored under ULO conditions requires investigation of the effect of low $\mathrm{O}_{2}$ on the synthesis and/or metabolism of fatty acids of these apples.

\section{Literature Cited}

Bangerth, F. and J. Streif. 1987. Effect of aminoethoxyvinylglycine and low-pressure storage on the post-storage production of aroma volatiles by Golden Delicious apples. J. Sci. Food. Agr. 41:351-360.

Bartley, I.M. 1985. Lipid metabolism of ripening apples. Phytochemistry 24:2857-2859

Bartley, I.M. 1986. Changes in sterol and phospholipid composition of 
apples during storage at low temperature and low oxygen concentration. J. Sci. Food Agr. 37:31-36.

Bohling, H. and H. Hansen. 1985. Untersuchung über das Lagerungsverhalten von Äpfeln in kontrollierten Atmosphären mit sehr niedrigen Sauerstoffanteilen. Erwerbsobstbau 27:80-84.

DePooter, H.L., M.R. Van Acker, and N.M. Schamp. 1987. Aldehyde metabolism and the aroma quality of stored Golden Delicious apples. Phytochemistry 26:89-92.

Drawert, F. 1975. Formation des aromes a différents stades de l'évolution du fruit; enzymes intervenant dans cette formation. In: Facteurs et Régulation de la Maturation des Fruits, Colloques Internationaux C.N.R.S. no. 238, Paris 1974, 57-62.

Drawert, F., W. Heimann, R. Emberger, and R. Tressl. 1972. Über die Biogenese von Aromastoffen bei Pflanzen und Früchten. IV Mitteilung; Bildung der Aromastoffe des Apfels im Verlauf des Wachstums und bei der Lagerung. Z. Lebensm. Unters. Forsch. 140:65-88.

Frenkel, C. and M.E. Patterson. 1973. Effect of carbon dioxide on the activity of succinic dehydrogenase in 'Bartlett' pears during cold storage. HortScience 8:395-396.

Halder-Doll, H. and F. Bangerth. 1987. Inhibition of autocatalytic $\mathrm{C}_{2} \mathrm{H}_{4}$ biosynthesis by AVG applications and consequences on the physiological behaviour and quality of apple fruits in cool storage. Scientia Hort. 33:87-96.

Hatfield, S.G.S. and B.D. Patterson. 1975. Abnormal volatile production by apples during ripening after controlled atmosphere storage. Colloques Internationaux C.N.R.S. 238:57-62.

Knee, M. and S.G.S. Hatfield. 1981. The metabolism of alcohols by apple fruit tissue. J. Sci. Food Agr. 32:593-600.

Lidster, P.D., K.B. McRae, and A.S. Katherine. 1981. Responses of 'McIntosh' apples to low oxygen storage. J. Amer. Soc. Hort. Sci. 106:159-162.

Neubeller, J. 1971. Beziehungen zwischen der Wasserabgabe von Äpfeln und der Zusammensetzung der Fruchtschale. Z. Lebensm. Unters Forsch. 147:86-93.
Nursten, H.E. 1970. Volatilecompounds: The aroma of fruits, p. 239-268. In: A.C. Hulme (ed.). The biochemistry of fruits and their products. Academic Press, London.

Patterson, B.D., S.G.S. Hatfield, and M. Knee. 1974. Residual effects of controlled atmosphere storage on the production of volatile compounds by two varieties of apples. J. Sci. Food Agr. 25:843-849.

Rolle, M. 1968. Untersuchung über freie Aminosäuren in Früchten und deren Verhalten während Wachstum und Reifung. Diss., Univ. of Karlsruhe, Germany.

Salunkhe, D.K. and J.Y. Do. 1976. Biogenesis of aroma constituents of fruits and vegetables. Crit. Rev. Food. Sci. Nutr. 6:161-190.

Schmitz, K.J. 1968. Über das Verhalten der Fette und Wachse von Apfelschalen während der Entwicklung der Früchte und bei ihrer Aufbewahrung in verschiedenen Lagersystemen. Erwerbsobstbau 10:147-149.

Schouten, S.P. 1988. ULO, Ethyleen en Kwaliteit. Fruitteelt 78:20-22.

Shatat, F., F. Bangerth, and J. Neubeller. 1978. Beeinflussung der Fruchtaromaproduktion durch drei verschiedene Lagerverfahren. Gartenbauwissenschaft 43:214-222.

Streif, J. 1981 . Vereinfachte Methode zur schnellen gaschromatographischen Bestimmung von flüchtigen Aromastoffen. Gartenbauwissenschaft 46:72-75.

Streif, J. 1985. Qualitätsproblemebei der Apfellagerung. Obstbau 10:177-179. Streif, J. and F. Bangerth. 1988. Production of volatile aroma substances by Golden Delicious apple fruits after storage for various times in different $\mathrm{CO}_{2}$ and $\mathrm{O}_{2}$ concentrations. J. Hort. Sci. 63:193-199.

Stumpf, P.K. 1980. The biochemistry of plants. In: P.K. Stumpf and E.E. Conn (eds.). Lipids: "Structure and functions", vol. IV, p. 177-202. Academic Press, New York.

Tressl, R., F. Drawert, and W. Heimann. 1970. Über die Biogenese von Aromastoffen bei Pflanzen und Früchten. VII Mitteilung-Fettsäuren des Bananenaromas; Verhalten von $\mathrm{C} 16$ und $\mathrm{Cl} 8$ Fettsäuren während der Reifung und ihre Verteilung in den Lipoiden. Z. Lebensm. Unters. Forsch. 142:391-397. 